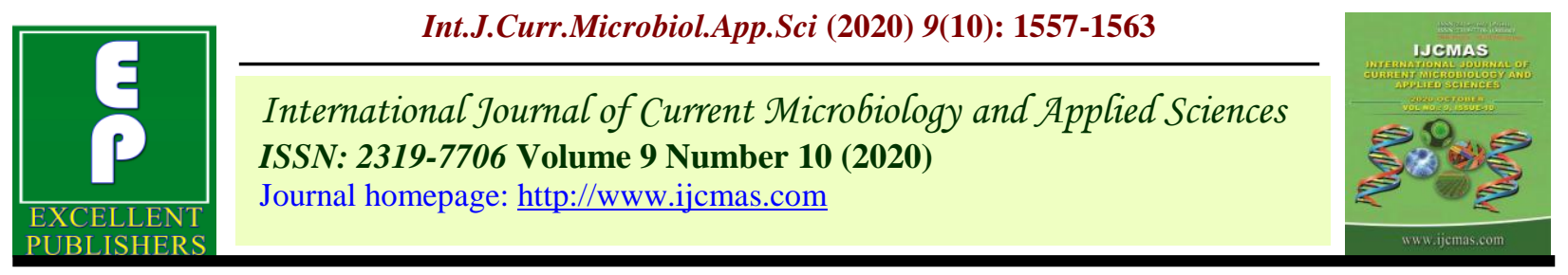

Original Research Article

https://doi.org/10.20546/ijcmas.2020.910.186

\title{
To Study the Genetic Variability, Heritability and Genetic Advance for Different Quantitative Characters in Indian Mustard (Brassica juncea L. Czern \& Coss)
}

\author{
Jarman Gadi, Nihar Ranjan Chakraborty and Zafar Imam*
}

Department of Genetics and Plant Breeding, PalliSikshaBhavana, Visva Bharati University, Birbhum-731326, West Bengal, India

*Corresponding author

\begin{tabular}{l} 
Ke y w o r d s \\
$\begin{array}{l}\text { Brassica juncea } \mathrm{L} . \\
\text { Genetic variability, } \\
\text { Heritability, } \\
\text { Genetic advance }\end{array}$ \\
Article Info \\
$\begin{array}{l}\text { Accepted: } \\
12 \text { September } 2020 \\
\text { Available Online: } \\
10 \text { October } 2020\end{array}$ \\
\hline
\end{tabular}

Keywords

Brassica juncea $\mathrm{L}$. Genetic variability, Heritability, Genetic advance

Accepted: Available Online: 10 October 2020

\section{A B S T R A C T}

\section{Introduction}

Indian mustard (B. juncea (Linn) Czern and Coss) popularly known as rai, raya or laha is one of the most important oil seed crops of the country and it occupies considerably large acerage among the Brassica group of oil seed crops. It is estimated the total production of
Thirty six diverse genotypes of Indian mustard (Brassica juncea L. Czern and Coss.) were evaluated for ten quantitative. The variability indicates that Genotypic coefficient of variation (GCV) was moderate for $50 \%$ flowering, days to maturity, total no. of siliqua per plant, biological weight, test weight and seed yield; low for plant height, no. of siliqua on main shoot, no. of seed per siliqua and harvest index. The estimation of phenotypic coefficient of variation (PCV) was high for biological weight; moderate for all characters except no. of seed per siliqua, it has low PCV. high heritability was recorded for the character days to maturity $(94.1 \%)$ followed by $50 \%$ flowering $(92.4 \%)$ and Test weight $(92.0 \%)$. The high heritability denotes high proportion of genetic effects in the determination of these characters and can be adopted for improving seed yield. Where as the low heritability was observed for the characters total number of siliqua per plant (48.7\%), Plant height (43.8\%), Number of seed per siliqua (39.8\%), number of siliqua on main shoot (22.3\%) biological Weight (17.9\%) and Harvest Index (7.1\%). Genetic advance as percentage of mean was observed high for the character is highest in days to $50 \%$ flowering $(20.995 \%)$, days to maturity $(21.320 \%)$, total no of siliqua per plant $(20.066 \%)$ and test weight $(35.936 \%)$. The value of genetic advance for plant height, no. of siliqua on main shoot, No. of seed per siliqua, biological weight, harvest index and seed yield are low. After studying such quantitative characters it was revealed that selection for number of test weight, total number of siliqua per plant, days to $50 \%$ flowering and days to maturity would be effective for improvement of seed yield in this population. 
principle cooking oil in the mustard growing areas of the country. Known for its great taste and subtle flavor, this vegetable oil is the world's second leading source of protein meal. Besides seeds, it is also used as condiments. Among rapeseed and mustard, rai (B. juncea) is very popular among the farmers due to higher yield and greater tolerance against lodging, shattering, drought condition, and relative diseases as well as the saline sodic conditions.

Brassica also performs well on neglected sites problems like soil acidity, low available nutrient content, poor drainage, drought, and soils with topographical limitations exist germplasm, which is prerequisite for any breeding programme, serves as a valuable source material as it provides scope for building for genetic variability. Study of variability, heritability and genetic advance in germplasm will help to ascertain the real potential of the genotype. Hence, this present study was planned to assess the variability, heritability and genetic advance for yield and other characters in a set of genotypes.

\section{Materials and Methods}

The present study was administered at the Agricultural research Farm Santiniketan, Department of Genetics and Plant Breeding (Palli Siksha Bhavana), Visvabharati University, Birbhum during rabi, 2017-18 and 2018-2019. Thirty -six diverse genotypes of Indian mustard (B. juncea) were planted in randomized block design with three replications in plot size of $1.5 \times 3 \mathrm{~m}$. The row to row and plant to plant distance was maintained at $30 \times 30 \mathrm{~cm}$. All recommended package of practices was applied to boost an honest crop. the info were recorded on ten characters, viz. days to maturity, plant height (cm), days to $50 \%$ flowering, total number of siliqua per plant, number of seeds per siliqua, number of siliqua on main shoot, arrangement of siliqua based upon angle from main shoot, seed yield per plant $(\mathrm{g}), 1000$ - seed weight (g), Harvest index (\%) and Biological weight (g).

\section{Results and Discussion} Variability, heritability and genetic
advance

The mean performances of mustard germplasm accessions for quantitative ten traits are presented in Table 1. The value mean, range, phenotypic coefficient of variation (PCV), genotypic coefficient of variation (GCV), heritability, genetic advance and genetic advance expressed as per cent mean for all the ten studied are presented in Table 1.

\section{Genotypic and phenotypic coefficient of variation}

Genotypic and Phenotypic coefficients of variation are simple measures of variability; these measures are commonly used for the assessment of variability. The relative values of coefficient give an idea about the magnitude of variability present in a genetic population. Thus, the components of variation such as genotypic coefficient of variation (GCV) and phenotypic coefficient of variation (PCV) were computed.

The phenotypic coefficients of variation were marginally higher than the corresponding genotypic coefficient of variation indicated the influence of environment in the expression of the character under study. Genotypic coefficient of variation (GCV) and phenotypic coefficient of variation (PCV) are categorized as low (less than 10\%), moderate (10-20\%) and high (more than 20\%) as suggested by Sivasubramanium and Madhavamenon (1973). 
Table.1 Phenotypic and Genotypic coefficients of Variability, Heritability and Genetic Advance for ten quantitative characters foe mustard germplasm

\begin{tabular}{|c|c|c|c|c|c|c|c|c|}
\hline & \multirow[t]{2}{*}{$\begin{array}{l}\text { Grand } \\
\text { mean }\end{array}$} & \multicolumn{2}{|c|}{ Range } & \multicolumn{2}{|c|}{$\begin{array}{l}\text { Coefficient of } \\
\text { variance }(\%)\end{array}$} & \multirow[t]{2}{*}{$\begin{array}{c}\text { Heritabilit } \\
\text { y }(\%)\end{array}$} & \multirow[t]{2}{*}{$\begin{array}{l}\text { Genetic } \\
\text { advance }\end{array}$} & \multirow{2}{*}{$\begin{array}{c}\text { Genetic advance } \\
\text { as a percent of } \\
\text { mean }\end{array}$} \\
\hline & & Max & Min & GCV & PCV & & & \\
\hline $50 \%$ flowering & 43.949 & 51.3333 & 33.0000 & 10.602 & 11.029 & 92.4 & 9.277 & 20.995 \\
\hline Plant height & 156.338 & 181.3000 & 128.4667 & 7.171 & 10.834 & 43.8 & 15.285 & 9.777 \\
\hline Days to maturity & 122.572 & 146.2667 & 94.8000 & 10.626 & 10.956 & 94.1 & 26.033 & 21.320 \\
\hline $\begin{array}{l}\text { No of silique on main } \\
\text { shoot }\end{array}$ & 32.071 & 39.1333 & 25.2667 & 7.748 & 16.417 & 22.3 & 2.416 & 7.352 \\
\hline $\begin{array}{l}\text { Total no siliqua per } \\
\text { plant }\end{array}$ & 73.073 & 96.4867 & 55.2200 & 13.953 & 19.988 & 48.7 & 14.3 & 20.066 \\
\hline No of seed per silique & 22.190 & 14.0333 & 10.8667 & 5.159 & 8.176 & 39.8 & 0.858 & 6.705 \\
\hline Biological weight & 12.798 & 28.3050 & 17.2133 & 10.247 & 24.249 & 17.9 & 1.979 & 8.919 \\
\hline Test weight & 4.477 & 6.4300 & 3.4333 & 18.199 & 18.969 & 92.0 & 1.610 & 35.936 \\
\hline Harvest Index & 15.928 & 18.6033 & 13.5583 & 4.771 & 17.904 & 7.1 & 0.417 & 2.620 \\
\hline Seed Yield & 3.969 & 5.6200 & 3.3650 & 12.817 & 18.182 & 49.7 & 0.739 & 8.919 \\
\hline
\end{tabular}


The genotypic and phenotypic variances are of little meaning as they do not have any clear limit and at the same time the categorization of the genotypic variance as low or high is difficult, rendering them unsuitable for comparison of two populations with desired precision when expressed in absolute values. To overcome this difficulty, the genotypic and phenotypic coefficient of variation, which are free from the unit of measurement, can be conveniently employed for making comparison between populations and different metric characters of population. In general phenotypic coefficient of variance was found to be higher than their genotypic coefficient of variance but the extent was quite small, indicating very less environmental influence on the expression of the characters. Genotypic coefficient of variation (GCV) was moderate for $50 \%$ flowering, Days to maturity, Total no. of siliqua per plant, biological weight, test weight and seed yield; low for plant height, no. of siliqua on main shoot, No. of seed per siliqua and harvest index. The estimation of phenotypic coefficient of variation (PCV) was high for biological weight; moderate for all characters except No. of seed per siliqua, it has low PCV. These findings are similar in agreement with earlier reported by Rai et al., 2005; Kumar and Mishra, 2006; Kumar et al., 2007; Nigam et al., 2009; Singh and Singh, 2010; Yadava et al., 2011; Yadav et al., 2012. The present study indicated higher contribution of biological yield per plant and 1000 seed weight towards genetic variability and there by suggesting that the parents chosen on the basis of these characters may be utilized in the crossing programme for obtaining good transgressive segments.

The estimates of PCV and GCV values for harvest index, number of siliqua on main shoot and biological weight which indicates the greater role of environmental factor influencing the factor of the component, on the other hand a very low difference was showed in days to $50 \%$ flowering, days to maturity and test weight indicates low sensitivity to environment and consequently greater role for genetic factor influencing the expression of these characters.

\section{Heritability and genetic advance}

The coefficient of variation indicates only the extent of variability existing for various characters but does not give any information about the heritable portion of it. Therefore, it is essential to know the heritability that permits the greater effectiveness of selection by separating out environmental influence from the total variability.

This indicates the accuracy with which genotypes can be identified by phenotypic performance. Breeder can attain maximum selection response if existence of variance is largely due to additive genes and estimated in terms of heritability.

In the present investigation an attempt has been made to estimate the heritability in broad sense by variance component analysis. The prediction regarding this aspect was made on the basis of percentage viz., low $(<50 \%)$, moderate $(50-70 \%)$ and high $(>70 \%)$ as suggested by Robinson (1966).

In present investigation the high heritability was recorded for the character Days to maturity (94.1\%) followed by $50 \%$ flowering $(92.4 \%)$ and Test weight $(92.0 \%)$. The high heritability denotes high proportion of genetic effects in the determination of these characters and can be adopted for improving seed yield. Where as the low heritability was observed for the characters total number of siliqua per plant (48.7\%), Plant height (43.8\%), Number of seed per siliqua $(39.8 \%)$, number of siliqua on main shoot $(22.3 \%)$ biological Weight (17.9\%) and Harvest Index $(7.1 \%)$. High or moderate heritability 
estimates for most of the traits had been reported earlier by Singh et al., (2003); Chauhan and Singh, (2008); Singh et al., (2011), Akabariand Niranjana (2015), Lyngdoh et al., (2017), Kumar et al., (2018).

\section{Genetic advance as percent of mean}

The heritability value alone however, provides no indication of the amount of genetic improvement that would result from selection of superior genotypes. The heritability estimates would be dependable if it is limited in a broad sense; additive and non-additive gene effects are accompanied with high genetic advance. To facilitate the comparison of progress in various characters of different genotypes, genetic advance was calculated as percentage of mean.

The magnitude of genetic advance as percentage of mean was categorized as high $(>20 \%)$, moderate $(10 \%-20 \%)$ and low (< $10 \%)$. Genetic advance as percentage of mean was observed high for the character is highest in days to $50 \%$ flowering (20.995\%), days to maturity $(21.320 \%)$, total no of siliqua per plant $(20.066 \%)$ and test weight $(35.936 \%)$. The value of genetic advance for plant height, no. of siliqua on main shoot, No. of seed per siliqua, biological weight, harvest index and seed yield are low. Same result observed by Singh et al., (2012), for plant height and biological weight by Goyat et al., (2012). High heritability with high genetic advance as percent of mean for days to $50 \%$ flowering, days to maturity and test weight suggesting predominant role of additive gene action for expression of these traits. As additive gene action is pronounced in the expression of these characters. Similar result were reported by Rai et al., (2005), Tripathi et al., (2013), Singh et al., (2013), Shekhawat et al., (2014), Lodhi et al., (2014), Hussain et al., (2016) and Samahegn and Tesfaye (2016), Kumar et al., (2018). Kumar et al., (2018) revealed the existence of considerable genetic variation among the breeding lines for the characters under study, which can be used for further selection and hybridization. Low heritability with low genetic advance as percent of mean for plant height, number of seed per siliqua, number of siliqua on main shoot, biological weight, harvest index and seed yield, showed the importance of dominance and epistatic effects in the inheritance of these characters and selection for these characters would be less effective.

A perusal of the table $\%$ where the results of PCV, GCV, heritability and genetic advance have been furnished revealed that selection for number of test weight, total number of siliqua per plant, days to $50 \%$ flowering and days to maturity would be effective for improvement of seed yield in this population.

\section{References}

Akabari, V. R. and Niranjana, M. (2015). Genetic variability and trait association studies in Indian mustard (Brassica juncea). I. J. of Agricultural Sciences. 11(1):35-39

Chauhan, S.S. and Singh, P.P. 2008.Genetic analysis for yield, its components and oil content in Indian mustard (Brassica juncea L. Czern\&Coss.). New Botanist, 35(1/4): 95-102.

Goyat, B.; Singh, D.; Ram avatar and Singh, A. 2012. Estimation of selection parameters in the elite gene pool of Indian mustard [Brassica juncea (L.) Czern\&Coss.]. Research on Crops, 13(3): 1098-1101.

Hussain, Md. A., Hossain, Md. S., Bhuiyan Md. S.R., Zeba N. and Mohsin S. Md. 2016. Field Performance and Genetic Analysis in Some Advanced Lines of Mustard (Brassica rapa L.). A Sci. J. Krishi Foundation The Agriculturists. 14(1): 112-121 
Kumar, A., Tiwari, S.,. Singh K., Tomar, A., and Singh, M.2018.Heritability, genetic advance and correlation coefficient analysis in Indian mustard (Brassica Juncea (L.) Czern\&Coss). Journal of Pharmacognosy and Phytochemistry; 6(1): 356-359

Kumar, M.; Singh, K. P. and Singh, D. 2007.Genetic divergence analysis for seed yield, its parameters and oil content in Indian mustard (Brassica junceaL. Czern and Coss). Research on Crops, 8(1): 183-185.

Kumar, S. and Mishra, M.N. 2007. Study on genetic variability, heritability and genetic advance in $\mathrm{F} 3$ populations in Indian mustard (Brassica junceaL. Czern\&Coss.). Inter. J. Pl. Sci., 2(1): 188-190.

Lodhi, B., Thakral, N.K., Ram, A. and Amit, S. 2014. Genetic variability, association and path analysis in Indian mustard (Brassica junceaL.) 26. J. Oilseed Bra. 5(1): 50-55.

Lyngdoh, Y., Kanaujia, S. P and Shah., P.2017Genetic variabilkity path coefficient analysis and character association in mustard germplasm. International Journal of Recent Scientific Research ResearchVol. 8, Issue, 8, pp. 19388-19391.

Nigam, R.; Alka. and Srivastava, A. 2009.Effect of genetic variability on seed yield and oil content in Indian mustard (Brassica junceaL. Czern\&Coss). Asian Journal of Bio Science, 4(2): 180-182.

Rai, S.K., Verma, A. and Pandey, D.D. 2005. Analysis of combining ability in Indian mustard (Brassica junceaL. Czern and Coss). Plant Archives. 5(1): 69-75.

Robinson, H., Robinson, F., Comstock, R.E. and Harvey, P.H.. 1966. Genotypic and Phenotypic Correlation in corn and their implication in selection,
Agronomy J. (40) 282-287.

Samahegn, Y and Tesfaye, M. 2016. Variability, Heritability and Genetic Advance Analysis for Some Morphological Characters in Oilseed Brassica Breeding Lines Molecular Plant Bree. 7(20): 1-8

Shekhawat, G. Jadeja C., Singh, J. and Shekhawat, R.S. 2014. Character association studies among yield and its component characters in Indian mustard (Brassica junceaL. Czern\&Coss). The Biosean. 9(2): 685688.

Singh, K.H., Gupta, M.C., Shrivastava, K.K. and Kumar, P.R. 2003. Combining ability and heterosis in Indian mustard. J. Oilseeds Res., 20(1): 3539.

Singh, S.K. and Singh, A.K. 2010.Interrelationship and path analysis for seed yield in Indian mustard. Indian Journal of Ecology, 37(1):8-12.

Singh., A., Ram, A., Dhiraj, S., Sangwan, O. and Balyan, P. 2013. Genetic variability, character association and path analysis for seed yield and component traits under two environments in Indian mustard $J$. Oilseed Bra, 4(1): 43-48.

Sivasubramanian, S.S. and Menon, M.P. 1973. Genotypic and Phenotypic variability in rice, Madras Agri. J. vo(60) 1093-1096.

Tripathi, N., Kumar, K., and. Verma O.P.2013. Genetic Variability, Heritability and Genetic Advance in Indian Mustard (Brassica junceaL. Czern and Coss.) for Seed Yield and it's Contributing Attributes Under Normal and Saline/Alkaline Int. J. Sci. Res. Condition Index Copernicus. 6.14 .

Yadav, R.K.; Chakravarty, A.; Kumar, N.; Yadav, J.R. and Ram Krishna 2012. Genetic variability and component 
analysis of some metric traits under sodic soil condition in Indian mustard (Brassica junceaL. Czern and Coss.). Progressive Agriculture, 12(2): 396401.

Yadava, D., S.C. Giri.,Vignesh, Muthusamy and K.V. Prabhu 2011. Genetic variability and trait association studies in Indian mustard (Brassica juncea). Indian Journal of Agricultural Sciences 81(8):712-716.

\section{How to cite this article:}

Jarman Gadi, Nihar Ranjan Chakraborty and Zafar Imam. 2020. To Study the Genetic Variability, Heritability and Genetic Advance for Different Quantitative Characters in Indian Mustard (Brassica juncea L. Czern \& Coss). Int.J.Curr.Microbiol.App.Sci. 9(10): 1557-1563. doi: https://doi.org/10.20546/ijcmas.2020.910.186 